\title{
O BEBÊ MEDICAMENTO: ASPECTOS E DISCUSSÕES NO ORDENAMENTO BRASILEIRO
}

\author{
SAVIOUR SIBLING: ASPECTS AND DISCUSSIONS IN THE BRASILIAN \\ $L A W$
}

Gustavo da Silva Ramos

\begin{abstract}
RESUMO
O objetivo do presente artigo é abrir discussões acerca do uso do "bebê medicamento" para tratar um filho que padece de doença grave. Muitas gerar um filho que seja geneticamente compatível com o irmão através do diagnóstico genético pré-implantcional pode ser a única salvação desse filho. Porém, a técnica levanta uma série de questionamentos, como a instrumentalização da vida e o melhor interesse do menor. Será que vale à pena se utilizar dessa meio para salvar uma vida? Quais seriam os limites de seu uso? Esses são levantamentos que este texto busca trabalhar.
\end{abstract}

Palavras-chave: Bebê medicamento. Bioética. Dignidade da pessoa humana.

\begin{abstract}
The purpose of this paper is to open discussions about the use of savior siblings to treat a child with sirious illness. Often, having a child who is genetically compatible with his sibling through preimplantation genetic diagnosis may be their only salvation. However, the technique raises a number of questions, such as the instrumentalization of life and the best interest of the minor. Is it worthwhile to use this means to save a life? What would be the limits of its use? These are surveys that this text seeks to work on.
\end{abstract}

Keywords: Saviour sibling. Bioethics. Dignity of human person planning.

\section{INTRODUÇÃO}

Maria Clara Reginato Cunha hoje com aproximadamente 7 anos de idade, foi a primeira "bebê medicamento" do Brasil. ${ }^{1}$ Concebida para doar o sangue de seu cordão umbilical pra sua irmã, Maria Vitória, que sofria de Talassemia Major, Maria Clara foi selecionada geneticamente para ser compatível com sua irmã enferma. A técnica consiste no chamado saviour sibling, ou bebê medicamento, em que se planeja um filho, através da técnica de fertilização in vitro, que seja compatível com um irmão que sofre de alguma doença e que precisa de algum transplante.

1 "Nasce no Brasil $1^{\circ}$ bebê selecionado geneticamente para curar irmã." Disponível em $<$ https://saude.estadao.com.br/noticias/geral,nasce-no-brasil-1-bebe-selecionado-geneticamente-paracurar-irma,835877> Acesso em 30 de junho 2019. 
A técnica pode causar certo espanto para quem houve de primeira mão, afinal surgem inúmeros questionamentos éticos em torno. Contudo, numa análise mais aprofundada, percebe-se que essa prática muito benéfica para a sociedade e que suas preocupações não merecem prosperar.

Há inúmeros valores e princípios em torno, como a dignidade da pessoa humana, a solidariedade familiar, o melhor interesse do menor, os preceitos bioéticos etc. É com base nesses princípios que o texto busca entender se: é ético que se permita a criação de um "bebê medicamento"?; e se sim, quais seriam os limites?

\section{A REPRODUÇÃO HUMANA ASSISTIDA: ASPECTOS GERAIS}

A reprodução humana assistida consiste em um conjunto de técnicas médicas que possibilitam a gravidez sem que haja concretamente a prática de ato sexual. Nas palavras de Marilena Villela Corrêa:

\footnotetext{
"reprodução assistida é o termo médico que descreve o conjunto heterogêneo de técnicas reunidas em torno de um eixo - o tratamento paliativo para situações de infertilidade. Desse conjunto de técnicas, fazem parte ainda as práticas de doação de material reprodutivo - doação de óvulos, espermatozoides, embriões -, utilizada suprir a sua carência nos casos assim identificados." ${ }^{2}$
}

A reprodução humana assistida é tida, portanto, como avanço técno-científico da biomedicina que possibilita uma série de vantagens para aqueles que se veem impossibilitados de procriar. Ela é uma alternativa para casais que sofrem de infertilidade, para casos de impossibilidade de gerar filhos, para casais homoafetivos que querem procriar, para mulheres que intentam gerar filhos sem a participação de um parceiro na busca pela sua autonomia reprodutiva, além de prevenir a transferência de doenças genéticas para a prole.

A esterilidade já é reconhecida pela OMS como doença, com a Pesquisa na Classificação Estatística Internacional de Doenças e Problemas Relacionados à Saúde - CID 10. ${ }^{3}$ Pode ser consequência de inúmeros quadros, como a endometriose, a síndrome do útero infantil etc. Diante desse contexto, a reprodução humana assistida se apresenta como tratamento para aqueles que sofrem por essas dificuldades, como meio de efetivar o exercício do planejamento familiar positivo.

2 CORRÊA, Marilena Villela. Novas Tecnologias Reprodutivas: limites da biologia ou biologia sem limites? Rio de Janeiro, 2001.

3 LOPES, C. A. C.; PAULICHI, Jaqueline da Silva. Responsabilidade civil oriunda da reprodução humana assistida heteróloga. In Direito, Constituição e Cidadania: contribuições para os objetivos de desenvolvimento do Milênio. 1ed.ARACAJU/SE: CONPEDI, 2016, v., p. 521. 
Desse modo, as técnicas de reprodução assistida são bem mais que mero avanço científico, são técnicas que funcionam a serviço do homem, possibilitando a concretização do princípio constitucional do livre planejamento familiar e, consequentemente, da autonomia reprodutiva, permitindo o pleno exercício da autonomia existencial da pessoa humana ao gerar sua prole, ao efetivar seu projeto parental, trazendo a materialização da dignidade da pessoa humana.

No entanto, a reprodução humana assistida, como qualquer outro avanço tecnológico que atinja o tecido social e que afete as relações sociais, também traz novas questões, novos desafios, como a possibilidade de se projetar um filho com características biológicas préselecionadas e, ainda, para que essa criança sirva de doador de tecidos para um irmão doente. Trata-se de uma questão decorrente das técnicas de reprodução assistida, dos quais cabe ao direito encontrar uma solução.

Essa possibilidade de se gerar um filho com características pré-determinadas para servir de doador para um irmão enfermo é conhecido como saviour sibling (bebê salvador ou bebê-medicamento, em português).

De primeira mão, a notícia de que uma criança pode ser gerada para servir ao tratamento de um irmão doente pode causar certo espanto e até preocupação com a saúde desse bebê. Contudo, ao analisar essa problemática mais a fundo, pode-se concluir que a prática pode ser algo muito favorável e que certos receios são infundados, desde, é claro, que se estabeleça certas limitações. É exatamente essa ideia que o presente artigo tenta trazer.

\section{O "BEBÊ MEDICAMENTO": ASPECTOS TÉCNICOS}

$\mathrm{Na}$ área médica é comum os profissionais se depararem com inúmeras doenças, causadas pelos mais diversos fatores, em que o paciente, ou para cura ou para tratamento, necessita de um doador compatível. Em se tratando de pessoas de uma mesma linha genética, as chances de compatibilidade aumentam e, em se tratando de irmãos, são maiores ainda. ${ }^{4}$

No caso da Talassemia Major ou Anemia de Cooley, doença causada por fatores genéticos, a simples transfusão do sangue do cordão umbilical de recém-nascido de indivíduo compatível pode curar a o paciente. Outro exemplo é o caso de um indivíduo com

\footnotetext{
${ }^{4}$ MORAIS, L. C. C. ; RAMOS, A. V. G. F. F. . Os Limites da Luta para Salvar um Filho: Questionamentos acerca dos Saviour Siblings. In: XXI Encontro Nacional do CONPEDI, 2012, Uberlândia. Anais do XXI Encontro Nacional do CONPEDI. Florianópolis: Fundação Boiteaux, 2012. Disponível em <http://www.publicadireito.com.br/artigos/?cod=67f7fb873eaf2952> Acesso em 19 de agosto 2019.
} 
leucemia, uma transfusão de sangue traz a cura, mas é imprescindível para um paciente que se submete a radioterapia.

Esses são alguns exemplos dentre inúmeras doenças em que um doador é a chance de salvar a vida de um paciente, porém ele não tem nenhum doador compatível. Em situações em que pais têm seu filho nessa condição, a ideia do saviour sibling é a única alternativa cientificamente viável.

A primeira etapa para se chegar ao "bebê medicamento" consiste na fertilização in vitro. Trata-se de uma das técnicas de reprodução assistida, em que a fecundação ocorre de forma extracorpórea e posteriormente os embriões são transferidos para o útero. Sobre a técnica, Ramírez-Gálvez explica:

“A FIV permite o encontro entre óvulo e espermatozoide fora do corpo da mulher. Grosso modo, o sêmen é obtido mediante masturbação e o óvulo mediante um procedimento bem mais complexo: o ovário é hiperestimulado com medicamentos hormonais para produzir mais do que um óvulo. O crescimento e amadurecimento são acompanhados mediante ultra-som e os óvulos são extraídos do corpo da mulher mediante procedimentos que utilizam anestesia local ou geral. Uma agulha é introduzida em cada um dos folículos maduros e seu conteúdo é aspirado. A agulha chega ao folículo através do fundo da cavidade vaginal ou pela uretra. Os óvulos e os espermatozoides de melhor qualidade são colocados em um meio de cultura, fora do corpo, para que aconteça a fecundação. Os pré-embriões são transferidos para o útero." 5

Porém, antes da transferência do embrião para o útero da mãe, é feito um exame nesse embrião, o chamado diagnóstico genético pré-implantacional - preimplantation genetic diagnosis (PGD). O PGD no âmbito do "bebê medicamento" é uma ferramenta para se verificar duas características do embrião: se ele apresenta a mesma doença genética do irmão enfermo (para os casos em que se busca o "bebê medicamento" para tratar de doenças genéticas); e para verificar se o embrião será geneticamente compatível com o irmão para doação, através da tipagem do sistema HLA.

Uma vez analisados esses dois aspectos, são selecionados os embriões que não apresentem a doença genética e que também sejam compatíveis. Em seguida esses embriões selecionados são transferidos para o útero de sua mãe. Ao nascerem, serão indivíduos compatíveis para doação ao irmão enfermo.

Trata-se de doação de tecidos renováveis, como o sangue periférico, a medula óssea e o sangue do cordão umbilical. Esses tecidos possuem as chamadas células tronco hematopoéticas, que servem para tratamento de inúmeras doenças.

RAMÍREZ-GÁLVEZ, Martha. Novas Tecnologias Reprodutivas Conceptivas: Fabricando a vida, fabricando o futuro. Campinas: Universidade Estadual de Campinas, 2003. Disponível em <http://repositorio.unicamp.br/bitstream/REPOSIP/279933/1/Ramirez-Galvez_MarthaCelia_D.pdf> Acesso em 19 de agosto 2019. 
Esse é o processo para a concepção e nascimento do filho tido como "bebê medicamento". Contudo, a etapa do PGD por si só levanta inúmeras questões de cunho ético, as quais, antes de dar prosseguimento a este trabalho, devem ser dirimidas.

\title{
4. QUESTÕES ÉTICAS ENVOLVENDO O DIAGNÓSTICO GENÉTICO PRÉ- IMPLANTACIONAL
}

O diagnóstico genético pré-implantacional (PGD), como exposto no tópico anterior, consiste em uma técnica biomédica executada durante o processo de fertilização in vitro que visa diagnosticar e selecionar aqueles embriões, antes da implantação no útero da mulher, que possuem algum problema genético que possa trazer complicações para a gestação e/ou para o futuro filho. Numa definição mais técnica:

\begin{abstract}
"o diagnóstico genético pré-implantacional (PGD) é uma técnica usada durante a reprodução humana assistida que investiga alterações cromossômicas e genéticas em embriões in vitro durante diferentes estágios de seu desenvolvimento e seleciona os embriões livres de alterações genéticas para implantação uterina."
\end{abstract}

Os embriões que apresentam problemas genéticos podem ser descartados ou doados para pesquisa, enquanto os remanescentes são aplicados na gestação, observada a legislação vigente.

A função do PGD é, a princípio, evitar que a futura prole não padeça por conta de doenças genéticas transmitidas pelos seus pais. É possível que um casal, mesmo que não sofra de algum tipo de infertilidade, mesmo que possa gerar filhos pela dita "via natural", através da reprodução sexuada, possa se valer da fertilização in vitro e do PGD para que seus filhos não carreguem gene defeituoso do qual um dos genitores é portador. O PGD examina os embriões gerados pela fertilização in vitro e seleciona aqueles que não transmitirão o gene causador da doença. ${ }^{7}$

Além desse exemplo, o diagnóstico genético pré-implantacional pode ser utilizado para evitar muitas outras doenças genéticas, como anemia falciforme, talassemia, doença de

6 POMPEU, Tainã Naiara; e VERZELETTI, Franciele Bona. Diagnóstico genético pré-implantacional e sua aplicação na reprodução humana assistida. Unibrasil, Curitiba, 2015.

7 Para ilustrar o caso, veja-se a aplicação do PGD para o tratamento da fibrose cística. A fibrose cística é uma doença autossômica recessiva causada por mutações no gene regulador de condutância transmembrana na fibrose cística. Essa condição genética pode causar doença pulmonar, insuficiência pancreática, íleo meconial, além de agenesia bilateral dos ductos deferentes, causando azoospermia obstrutiva e infertilidade masculina. Durante o processo de fertilização in vitro, é feito o PGD, que permite identificar aqueles embriões portadores dos genes causadores da fibrose cística. Apenas os embriões que não sejam portadores são transferidos para o útero, garantindo assim a geração de descendentes saudáveis. (BIAZOTTI, Maria Cristina Santoro. Diagnóstico genético pré-implantacional na fibrose cística: relato de caso. São Paulo, 2015). 
Huntington, síndrome de Marfan, doença de Gaucher, dentre inúmeras outras. ${ }^{8}$ O PGD pode também ser utilizado para os casos de doenças ligadas ao sexo, isto é, doenças genéticas que só se manifestam no sexo masculino, como a hemofilia, ou no feminino, como a síndrome de Turner. Daí é feita a chamada sexagem, em que se seleciona os embriões por sexo, transferindo para o útero apenas aqueles do sexo que não manifesta a doença genética.

A técnica do diagnóstico genético pré-implantacional coaduna com um cenário de proteção da dignidade da pessoa humana, pois, além de impedir frustração dos pais, busca principalmente evitar uma vida de sofrimento para os filhos. O PGD evita que a prole manifeste doenças graves que lhes causariam sérios infortúnios para suas vidas, além de não permitir a perpetuação dessa herança genética falha para seus descendentes.

Esses são aspectos positivos relativos ao diagnóstico genético pré-impalntacional, demonstrando como esse é um procedimento médico imprescindível dentro das técnicas de reprodução humana assistida extracorpórea para que o casal realize de forma bem sucedida seu projeto parental. Porém, o PGD não se limita nessas condições. Seus benefícios são bem amplos, refletindo no princípio constitucional do livre planejamento familiar, ao qual cabem algumas considerações.

No entanto, embora o PGD possa ser uma solução para inúmeros casos de doenças genéticas, ele também pode ser utilizado para outros fins não tão nobres. A técnica, por fazer uma análise genética dos embriões na fertilização in vitro, pode ter outro fim que não evitar o desenvolvimento de doenças genéticas: a finalidade de determinar características biológicas da futura criança, como sexo, cor dos olhos, altura, cor de pele, cabelo etc... por mero capricho, sem nenhuma relação com a prevenção de doenças. Um estudo de cientistas estadunidenses já prevê que será possível ranquear o nível de QI dos embriões dentro de dez anos. ${ }^{9}$ Esses são fins meramente superficiais, os quais geram no mínimo questionamentos bioéticos.

Indo mais além, o PGD possibilita a seleção e o descarte daqueles embriões que a sociedade por descriminação venha a considerar "defeituosos", como por exemplo aqueles embriões que apresentam a trissomia do cromossomo 21 , alteração genética causadora da síndrome de Down. Tal uso configuraria nada mais do que a prática de eugenia, em que se busca fazer uma "higienização genética social", ambicionando a criação de uma "sociedade

8 FÉO, Christina de Oliveira. A seleção de embriões e problemas éticos. In: Arthur Magno e Silva Guerra. (Org.). Biodireito e Bioética: uma introdução crítica. Rio de Janeiro: América Jurídica, 2005, p. 262.

9 "IVF couples could be able to choose the 'smartest' embryo." Disponível em $<$ https://www.theguardian.com/society/2019/may/24/ivf-couples-could-be-able-to-choose-the-smartestembryo> Acesso em 30 de junho 2019. 
de seres humanos perfeitos" através da exclusão daqueles que não atendam ao ideal de um “pedigree genético ${ }^{10 "}$. É valido lembrar que esses tipos de preceitos compunham o ideal de regimes totalitaristas, como o nazismo alemão.

Hoje em dia os horrores do nazismo e do totalitarismo em torno da eugenia são bem conhecidos, porém poucos percebem como em pleno século XXI como o fantasma da eugenia é muitas vezes ressuscitado. "Os ideais do nazismo já não existem mais, porém a ideologia da superioridade do homem permanece". ${ }^{11}$

A técnica do PGD, dependendo de como ela é utilizada na reprodução humana assistida, pode se valer de fundamentos eugênicos para discriminar os embriões que não atendam ao ideal de superioridade genética que atrai os pais, ideal esse muitas vezes definido por elementos de ordem sociocultural. Como já exposto, a discriminação daqueles embriões que portem genes causadores de doenças faz sentido dentro de uma programática de proteção da dignidade da pessoa humana, porém a discriminação para outros fins que não os da medicina preventiva configuraria a prática de eugenia e contraria preceitos da bioética.

Nesse sentido, Oliveira alerta para a discriminação embrionária que tende a aumentar com os avanços da biotecnologia:

\begin{abstract}
"Os exames de laboratório estão cada vez mais complexos, sendo consequentemente também mais precisos, vindo a permitir a visualização dos mais variados problemas, assim como o respectivo tratamento, que pode ser até a eliminação da vida. É o que as vezes, ocorre, com a vida embrionária que não corresponde ao ideal de perfeição ditado pelo sistema e desejado pelos genitores. Desejada ou não, esta é a realidade atual, e retrata uma forma de discriminação que tende a aumentar com o decorrer dos tempos e com os avanços biotecnológicos por vir." 12
\end{abstract}

Dessa forma, embora o PGD possa trazer inúmeros benefícios no âmbito da medicina preditiva, ele pode servir a fins de "melhoramento da raça" como na seleção de embriões de pele clara ou do sexo masculino ou que não apresentem outras características consideradas marginais pela sociedade, como a síndrome de Down. Para afastar o espírito de discriminação e de eugenia, que se recusa em preservar a rica variabilidade genética da espécie humana, é necessário que se estabeleça limites ao PGD, à luz da bioética e da dignidade da pessoa humana.

10 DINIZ, Debora. Autonomia reprodutiva: um estudo de caso sobre a surdez. Cadernos de Saúde Pública (FIOCRUZ), Rio de Janeiro, v. 19, n.1, 2003, p. 177.

11 OLIVEIRA, Simone Born de. Da bioética ao biodireito: manipulação genética e dignidade humana. 4ed. Curitiba: Juruá editora, 2005, v. 1, p. 101.

12 Ibidem, p. 103. 
No âmbito do ordenamento jurídico brasileiro, embora o legislativo até o momento não tenha regulado a questão, a Resolução CFM n 2.168/2017 permite o PGD apenas para diagnosticar doenças genéticas em relação ao futuro filho.

No entanto, em se tratando do "bebê medicamento", surgem questionamentos quanto à ética da prática. Não se estaria violando a dignidade da pessoa humana do futuro filho? Não seria uma espécie de instrumentalização da vida, ao tratar o ser humano como meio e não como um fim em si mesmo? E o bem estar da criança? Utilizá-la como doador do irmão não pode lhe causar graves danos? Essas são questões de cunho bioético que norteiam o debate sobre o "bebê medicamento".

\section{A INSTRUMENTALIZAÇÃO DA VIDA}

Uma das maiores preocupações em torno do "bebê medicamento" é sobre sua instrumentalização, uma coisificação da criança. É uma percepção que feriria a própria ideia de isonomia entre os filhos, pois paciente seria tratado e o seu irmão seria como um mero medicamento que pode ser aproveitado sem que se leve seu bem estar em conta e ser descartado após servir o seu propósito. Tal proposta é algo completamente rechaçado e que não encontra fundamento algum no ordenamento jurídico pátrio.

O bem estar do menor será sempre levado em conta, como será demonstrado no próximo tópico. Contudo, ainda assim, há que defenda que haveria uma grave violação à dignidade da pessoa humana, por se por uma vida a serviço de outra. ${ }^{13}$ Isso porque, a dignidade da pessoa humana se inspira na proposição Kantiana de que o ser humano é um fim em si mesmo, jamais pode ser instrumentalizado. No entanto, segundo Wilkinson ${ }^{14}$, a ética de Kant não consiste em proibir que as pessoas sejam meios, mas proibir que elas fossem utilizadas meramente e somente como meios. A todo momento instrumentalizamos outro indivíduo. Em uma simples transfusão de sangue, por exemplo, está-se utilizando o doador como meio. Isso não necessariamente é algo que fere a dignidade da pessoa humana. A própria ideia de se conceber um filho pode ser entendida como a instrumentalização do menor como meio para satisfazer um projeto parental. Contudo, não há que se falar em violação da dignidade da pessoa humana nesses casos.

13 "Doctor plans UK 'designer baby' clinic" Disponível em <http://news.bbc.co.uk/2/hi/health/1702854.stm> Acesso em 30 de junho 2019.

14 WILKINSON, S. and SHELDON, S. (2004). Should selecting saviour siblings be banned? Journal of Medical Ethics 30 533-537" Disponível em <https://jme.bmj.com/content/medethics/30/6/533.full.pdf> Acesso em 30 de junho 2019. 
Da mesma forma, conceber um filho para que possa tratar um irmão não implica diretamente em violação da dignidade da pessoa humana. Não se sugere que ele receberá um cuidado diferente, que será criado com menos afeto e será descartado. Ainda assim, seu bem estar deve sempre ser levado em conta, desde a concepção, respeitando sua dignidade e os preceitos da bioética.

Contudo, antes de se analisar mais a fundo a relação da bioética com o tema do "bebê medicamento", é necessário que se faça algumas considerações sobre os princípios que legitimam seu uso. São eles o livre planejamento familiar e a solidariedade familiar.

\section{AS BASES PRINCIPIOLÓGICAS DO "BEBÊ MEDICAMENTO"}

O princípio do livre planejamento familiar, hoje previsto no art. $226, \S 7^{\circ}$, da Constituição da República, sofreu profundas transformações até ser promovido ao status de princípio constitucional no ordenamento pátrio. É a ideia de desenvolvimento da família como espaço para autodeterminação existencial, independente de modelos familiares historicamente pré-estabelecidos, com a livre escolha de desenvolvimento da prole e livre da intervenção estatal impositiva. A definição legal, prevista no art. $2^{\circ}$ da Lei $n^{\circ}$ 9.263/96, traz o planejamento familiar como o "conjunto de ações de regulação da fecundidade que garanta direitos iguais de constituição, limitação ou aumento da prole pela mulher, pelo homem ou pelo casal." Para Schreiber,

"o planejamento familiar, como se vê, consiste em espaço de exercício da autonomia existencial dos integrantes da família. Ao Estado compete não interferir nas livres escolhas dos membros da família, restringindo-se a propiciar os recursos necessários ao pleno exercício dessa liberdade."15

Essa concepção de planejamento familiar e do próprio conceito de família, trazidos pela Constituição Federal de 1988, tem como causa os avanços tecno-científicos da biomedicina voltados para a reprodução humana. Nas palavras de Schettini:

“(...) Tais possibilidades revolucionaram não só aspectos jurídicos, mas também a própria concepção de família, ou seja, os avanços científicos e tecnológicos, especialmente no que diz respeito às técnicas médicas utilizadas para a reprodução humana, têm demonstrado a necessidade de repensar conceitos antes preestabelecidos e considerados incontestáveis. (...)

O modelo de família codicista (patriarcal, matrimonializada, hierarquizada e calcada em presunções de filiação) desvanece diante das novas perspectivas abertas pela ciência, especialmente pela possibilidade de realização do projeto parental de forma individual. Assim, essas novas possibilidades médicas permitem que mulheres sozinhas realizem o projeto de maternidade, ou que casais

15 SCHREIBER, Anderson. Manual de Direito Civil Contemporâneo. 2. ed. São Paulo: Saraiva Educação, 2019, p. 864-865. 
homoafetivos tenham filhos, concretizando o direito ao livre planejamento familiar garantido na Constituição Federal." 16

A Constituição Federal de 1988 cedeu lugar à família democrática, com a formação de novos núcleos familiares. Trata-se da família como espaço para o desenvolvimento da personalidade de seus membros e de promoção de sua dignidade. ${ }^{17}$

Atinente ao princípio do livre planejamento familiar, o direito à autonomia reprodutiva é um conceito que também sofreu grandes transformações. Entendida como um direito decorrente e essencial do princípio constitucional do planejamento familiar, a autonomia reprodutiva trilhou um longo caminho até ser reconhecido como direito fundamental. A procriação foi por muito tempo considerada uma faculdade. O conceito moderno de autonomia reprodutiva consiste no:

“(...) reconhecimento do direito de escolha de mulheres e homens, em conjugalidade, formal ou informal, ou individualmente, a respeito do número de filhos e da distância entre eles, bem como o acesso às informações aos métodos e técnicas disponíveis e cientificamente aceitos tanto para a contracepção quanto para a procriação." 18

Pode-se dizer que o ordenamento pátrio consagra a autonomia reprodutiva através de dois fundamentos: pelo livre planejamento familiar; e pelo direito ao corpo. ${ }^{19}$ Como leciona Konder:

“(...) deve-se concluir que é possível reconhecer a existência, no ordenamento brasileiro, de uma autonomia reprodutiva, que garante a defesa da liberdade de escolher se, quando e como procriar e desenvolver a atividade de genitor. A justificação dessa prerrogativa em abstrato, amparada no direito ao livre planejamento familiar e no direito ao corpo (...)"20

Essa ideia de autonomia reprodutiva e planejamento familiar, como autonomia para procriar, "concorre para a constituição da personalidade dos próprios sujeitos que a promovem. Reproduzir alcança status de recurso à plena formação individual." ${ }^{21}$ Portanto, nesse novo modelo de família, a procriação é assegurada como "verdadeiro exercício de um

16 SCHETTINI, Beatriz. Planejamento familiar e a gestação de substituição: os limites ao exercício do direito de procriação. In: Walsir Edson Rodrigues. (Org.). Direito das Famílias: novas tendências. 1ed.Belo Horizonte: D'Plácido editora, 2015, v. 1, p. 33-34.

17 Ibidem.

18 ALMEIDA JUNIOR, Vitor de Azevedo. Parentalidade tardia e reprodução assistida: os limites do direito ao planejamento familiar no ordenamento jurídico brasileiro. In Revista de Direito Privado: RDPriv, v. 14, n. 54, p. 279-314, abr./jun. 2013.

19 KONDER, Carlos Nelson. Autonomia reprodutiva e novas tecnologias no ordenamento brasileiro: violações e ameaças ao direito a gerar e a não gerar filhos. Rio de Janeiro, 2016.

20 Ibidem.

21 SCHETTINI, Beatriz. Planejamento familiar e a gestação de substituição: os limites ao exercício do direito de procriação. In: Walsir Edson Rodrigues. (Org.). Direito das Famílias: novas tendências. 1ed. Belo Horizonte: D'Plácido editora, 2015, v. 1, p. 35. 
direito reprodutivo estabelecido pela Constituição, desde que exercido de forma responsável e pautado na dignidade humana." 22

Em se tratando de reprodução humana assistida, é evidente que a técnica representa uma concretização e uma plena efetivação do princípio do planejamento familiar. Independente das limitações naturais, ela permite o acesso de qualquer cidadão ao livre exercício do direito à autonomia reprodutiva, sendo esta uma extensão da esfera existencial, da personalidade dos genitores. O próprio PGD permite que esse planejamento familiar se faça de forma segura, sem que gere riscos de complicação à gravidez e ao futuro filho. Inclusive, o próprio comando constitucional que trata do planejamento familiar determina, ainda, que "o Estado disponibilize para o exercício deste direito os recursos educacionais e científicos cabíveis, além de vedar qualquer forma de coerção por parte de instituições oficiais ou privadas que interfira no livre planejamento familiar" (art. 226, $\S 7^{\circ}$ ).

Em se tratando do "bebê medicamento", o livre planejamento familiar justifica o seu uso. A ideia de não intervenção do Estado impede interferência na prole. Contudo, o livre planejamento é o que fundamenta mas também é o que limita a prática, através da dignidade da pessoa humana e da paternidade responsável, segundo o dispositivo constitucional.

Pode-se entender que a prática do "bebê medicamento" encontra seu fundamento na solidariedade familiar. O princípio do melhor interesse do menor está em jogo em dois lados, o do filho enfermo e o do filho a porvir. Poderiam ser considerados interesses conflitantes, mas o princípio da solidariedade nas relações familiares é o que justifica a possibilidade de se lançar mão de tal procedimento. Segundo Paulo Lôbo, a solidariedade "significa um vínculo de sentimento relacionamento guiado, limitado e autodeterminado que compele à oferta de ajuda, apoiando-se em uma mínima similitude de certos interesses e objetivos (...)", ${ }^{23}$ Nesse sentido, esse princípio forma o alicerce da possibilidade do "bebê medicamento".

\section{A BIOÉTICA EM TORNO DO "BEBÊ MEDICAMENTO"}

De maneira geral, pode-se entender como objetivo da bioética "a busca de benefícios e da garantia do ser humano, tendo como fio condutor o princípio da defesa da dignidade

22 Ibidem, p. 37.

23 LÔBO, Paulo . Princípio da solidariedade familiar. In: Rodrigo da Cunha Pereira. (Org.). Família e solidariedade. 1ed. Rio de Janeiro: Lumen Juris, 2008, v. 1, p. 1-17. 
humana". ${ }^{24}$ A bioética portanto consiste em "guiar o médico na sua relação com paciente em geral em toda ação ou escolha no campo biomédico. Visam fornecer diretrizes de comportamento, 'mas é o valor ético do bem da pessoa como fim último a ser atingido que confere o sentido último da ação"”, 25

A bioética, portanto, como se pode depreender, tem por base a dignidade da pessoa humana. Dando mais concretude, a bioética traz o princípio da beneficência, ou não maleficência, que diz respeito a sempre fazer bem ao paciente. $O$ princípio tem origens no paradigma hipocrático: “as máximas deste critério são: 'fazer o bem', 'não causar dano', 'cuidar da saúde', 'favorecer a vida"'. ${ }^{26}$ Esse preceito se ao dever médico de evitar danos corporais e mentas. Como explica Oliveira: "a ação dos prestadores de serviços, instituições e profissionais deve estar voltada sempre para a melhoria da saúde e o bem-estar da clientela. (...) o bem da pessoa é prioritário, em relação aos interesses da sociedade e da

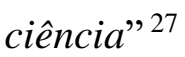

Por conseguinte, o princípio da beneficência, à luz da reprodução assistida, se aplica no sentido de resguardar a dignidade da pessoa humana em relação ao filho à porvir. A questão é evitar o nascimento de indivíduo que virá ao mundo para sofrer, salvaguardando a dignidade da pessoa humana. "A vida deve ser acompanhada de dignidade no viver". ${ }^{28}$

Em se tratando de transplante das células tronco hematopoéticas do cordão umbilical, não há qualquer risco a criança. Entretanto, em relação à medula óssea ou ao sangue periférico, trata-se de procedimentos bem mais invasivos. Nesse sentido, haveria uma violação da bioética e da dignidade da pessoa humana, uma vez que se trata de absolutamente incapaz.

Sobre essa questão, embora ainda não haja lei no Brasil específica sobre o tratamento através do "bebê medicamento", há duas fontes que podem trazer um norte para essa pratica. A primeira é a Resolução CFM n ${ }^{\circ} 2.168 / 2017$, que traz disposições sobre a reprodução assistida. No capítulo VI, que trata justamente sobre o PGD, encontra-se a seguinte disposição:

\footnotetext{
“As técnicas de RA também podem ser utilizadas para tipagem do sistema HLA do embrião, no intuito de selecionar embriões HLA-compatíveis com algum irmão já afetado pela doença e cujo tratamento efetivo seja o transplante de célulastronco, de acordo com a legislação vigente."
}

OLIVEIRA, Fátima. Bioética - uma face de cidadania. 2. ed. São Paulo: Moderna, 1997, p. 47-48.

25 OLIVEIRA, Simone Born de. Da bioética ao biodireito: manipulação genética e dignidade humana. 4ed. Curitiba: Juruá editora, 2005, v. 1, p. 47.

26 Ibidem, p. 49.

27 Ibidem, p. 49.

28 Ibidem, p. 54. 
Embora a resolução do CFM seja apenas norma deontológica, não tenha força vinculante, ela preenche uma lacuna no ordenamento, reduz a margem de insegurança jurídica. De acordo com essa resolução, o bebê medicamento é permitido, desde que seja para transplante de células tronco apenas. Nesse caso, o meio de se obter células tronco do recém-nascido é através de do sangue do cordão umbilical, do sangue periférico ou da medula óssea. Como já exposto, é onde se encontram as células troco hematopoéticas.

Além disso, a resolução condiciona esse transplante à legislação vigente. Deve-se então buscar esses parâmetros na Lei n ${ }^{\circ}$ 9.434/97, que regula o transplante de órgãos. $\mathrm{O}$ art. $9^{\circ}, \S 6^{\circ}$ da referida Lei Federal estabelece o seguinte:

“Art. $9^{\circ}$ - É permitida à pessoa juridicamente capaz dispor gratuitamente de tecidos, órgãos e partes do próprio corpo vivo, para fins terapêuticos ou para transplantes em cônjuge ou parentes consangüíneos até o quarto grau, inclusive, na forma do $\S 4$ o deste artigo, ou em qualquer outra pessoa, mediante autorização judicial, dispensada esta em relação à medula óssea.

$\S 6^{\circ} \mathrm{O}$ indivíduo juridicamente incapaz, com compatibilidade imunológica comprovada, poderá fazer doação nos casos de transplante de medula óssea, desde que haja consentimento de ambos os pais ou seus responsáveis legais e autorização judicial e o ato não oferecer risco para a sua saúde."

Nesse sentido, percebe-se que a Lei só permite o transplante apenas da medula óssea do menor incapaz, atendendo a quatro requisitos: compatibilidade; autorização judicial; consentimento de ambos os pais; e não haver risco para saúde.

Trata-se de uma proteção rigorosa e acertada do menor incapaz, que não tem qualquer discernimento para exercer sua autonomia e tomar decisões dessa magnitude. Principalmente em se tratando de recém-nascido, é necessário rigoroso cuidado para procedimentos invasivos, prestigiando, assim, o preceito bioético da não meleficência.

Contudo, como já dito, é uma Lei Federal que trata apenas de transplante, não sobre reprodução assistido ou "bebê medicamento". Resta claro que não é permitido procedimentos mais invasivos do que o transplante de medula óssea, como o transplante de órgãos, que poderia comprometer a integridade e saúde da criança. Contudo, quanto aos procedimentos menos invasivos, como a transfusão de sangue e o sangue do cordão umbilical, dever-se-ia entender que eles seriam autorizados justamente por serem menos invasivos. Não há lei, porém, que trate do assunto.

A única possibilidade que se tem até o momento é o Projeto de Lei no 7880 de 2017, de autoria do Deputado Federal (MDB-MT), que busca acrescentar o art. $9^{\circ}$-A à Lei do Planejamento Familiar, estabelecendo o seguinte:

"Art. 9-A. É permitida a implantação de embriões humanos produzidos por fertilização in vitro, cujo diagnóstico genético pré-implantacional demonstrar ausência de patologia geneticamente determinada, com intuito de doação de 
células ou tecidos para utilização terapêutica em irmão que a apresente, de acordo com as normas regulamentadoras.

Parágrafo único. O procedimento não provocará dano irreversível ao doador e respeitará sua autonomia."

O Projeto de Lei, entretanto, possui alguns defeitos. Primeiramente, ele prevê a utilização do bebê medicamento apenas para as doenças genéticas, o que gera dois problemas: a um, não há autorização do uso do PGD para que se busque um embrião que seja compatível com o irmão enfermo; a dois, trata-se apenas do tratamento de patologia genética apresentada pelo irmão, o que excluiria o tratamento de outras doenças que não sejam genéticas. No caso da Talassemia Major, por exemplo, dependendo deste Projeto de Lei, o filho enfermo poderia ser tratada por transfusão do sangue do cordão umbilical pelo irmão criado para tal. Porém, num caso de leucemia, não poderia, porque não se trata de doença geneticamente determinada.

Ademais, o parágrafo único do PL diz que não pode haver dano irreversível ao doador. Então se admite algum dano reversível? O PL sugere que por esse procedimento possa causar algum dano ao "bebê medicamento".

Por fim, o PL não estabelece qualquer parâmetro sobre a aplicação deste tipo e procedimento. Precisaria de autorização da Justiça? É necessário consentimento dos pais? Trata-se de questões que ficam sem resposta pelo texto do PL, que se entrasse em vigor hoje como lei causaria enorme imbróglios jurídicos.

\section{CONSIDERAÇÕES FINAIS}

Através dos pontos analisador, pode-se concluir que a o uso da técnica do "bebê medicamento", embora cause espanto em alguns, não deve ser vedada. Não há motivos para acreditar que se está instrumentalizando uma vida de maneira a desvalorizá-la perante uma outra. Pode-se muito bem (e deve-se) atribuir mesmo valor àquele filho que foi concebido para salvar seu irmão. Não há nada no uso do "bebê medicamento" que viole sua dignidade.

Ademais, o "bebê medicamento" pode ser a única alternativa para uma doença. Os eventuais riscos de uma má prática do "bebê medicamento" não se compara às trágicas mortes das crianças que poderiam ter sido salvas.

Contudo, em prol da integridade e da dignidade do futuro filho, limites devem ser estabelecidos. Procedimentos invasivos não podem ser aplicados àqueles absolutamente incapazes, que estão em uma condição de vulnerabilidade, além de se exigir uma série de requisitos, visando resguardar os direitos do menor vulnerável. Nesse sentido, a Lei de 
Transplantes agiu acertadamente. Contudo, ela não supre todas as lacunas para uma aplicação plenamente segura do "bebê medicamento".

\section{REFERÊNCIAS}

ALMEIDA JUNIOR, Vitor de Azevedo. Parentalidade tardia e reprodução assistida: os limites do direito ao planejamento familiar no ordenamento jurídico brasileiro. In Revista de Direito Privado: RDPriv, v. 14, n. 54, p. 279-314, abr./jun. 2013.

BARBOZA, Heloisa Helena. Reprodução assistida; questões em aberto. In 10 anos de vigência do Código Civil brasileiro de 2002. Estudos em homenagem ao professor Carlos Alberto Dabus Maluf. Christiano Casetari, coord. São Paulo: Saraiva, 2013.

BIAZOTTI, Maria Cristina Santoro. Diagnóstico genético pré-implantacional na fibrose cística: relato de caso. São Paulo, 2015.

CORRÊA, Marilena Villela. Novas Tecnologias Reprodutivas: limites da biologia ou biologia sem limites? Rio de Janeiro: Eduerj, 2001.

DINIZ, Debora. Autonomia reprodutiva: um estudo de caso sobre a surdez. Cadernos de Saúde Pública (FIOCRUZ), Rio de Janeiro, v. 19, n.1, p. 175-181, 2003.

FÉO, Christina de Oliveira. A seleção de embriões e problemas éticos. In: Arthur Magno e Silva Guerra. (Org.). Biodireito e Bioética: uma introdução crítica. Rio de Janeiro: América Jurídica, 2005.

KONDER, Carlos Nelson. Autonomia reprodutiva e novas tecnologias no ordenamento brasileiro: violações e ameaças ao direito a gerar e a não gerar filhos. Rio de Janeiro, 2016.

LÔBO, Paulo. Princípio da solidariedade familiar. In: Rodrigo da Cunha Pereira. (Org.). Família e solidariedade. 1ed. Rio de Janeiro: Lumen Juris, 2008, v. 1, p. 1-17.

LOPES, C. A. C.; PAULICHI, Jaqueline da Silva. Responsabilidade civil oriunda da reprodução humana assistida heteróloga. Direito, Constituição e Cidadania: contribuições para os objetivos de desenvolvimento do Milênio. 1ed. ARACAJU/SE: CONPEDI, 2016, v., p. 518-548.

MORAIS, L. C. C. ; RAMOS, A. V. G. F. F. . Os Limites da Luta para Salvar um Filho: Questionamentos acerca dos Saviour Siblings. In: XXI Encontro Nacional do CONPEDI, 2012, Uberlândia. Anais do XXI Encontro Nacional do CONPEDI. Florianópolis:

Fundação Boiteaux, 2012. Disponível em <http://www.publicadireito.com.br/artigos/?cod=67f7fb873eaf2952> Acesso em 19 de agosto 2019.

OLIVEIRA, Fátima. Bioética - uma face de cidadania. 2. ed. São Paulo: Moderna, 1997.

OLIVEIRA, Simone Born de. Da bioética ao biodireito: manipulação genética e dignidade humana. 4ed. Curitiba: Juruá editora, 2005, v. 1, p. 1-225.

RAMÍREZ-GÁLVEZ, Martha. Novas Tecnologias Reprodutivas Conceptivas: Fabricando a vida, fabricando o futuro. Campinas: Universidade Estadual de Campinas, 2003.

Disponível em <http://repositorio.unicamp.br/bitstream/REPOSIP/279933/1/RamirezGalvez_MarthaCelia_D.pdf $>$ Acesso em 19 de agosto 2019. 
POMPEU, Tainã Naiara; e VERZELETTI, Franciele Bona. Diagnóstico genético préimplantacional e sua aplicação na reprodução humana assistida. Unibrasil, Curitiba, 2015.

SCHETTINI, Beatriz. Planejamento familiar e a gestação de substituição: os limites ao exercício do direito de procriação. In: Walsir Edson Rodrigues. (Org.). Direito das

Famílias: novas tendências. 1ed.Belo Horizonte: D'Plácido editora, 2015, v. 1, p. 09-221.

SCHREIBER, Anderson. Manual de Direito Civil Contemporâneo. 2. ed. São Paulo:

Saraiva Educação, 2019.

WILKINSON, S. and SHELDON, S. (2004). Should selecting saviour siblings be banned? Journal of Medical Ethics, 30 533-537” Disponível em

$<$ https://jme.bmj.com/content/medethics/30/6/533.full.pdf> Acesso em 30 de junho 2019. 